\title{
Learners' Needs Analysis of a New Optional College English Course-Interpreting for Non-English Majors
}

\author{
Ping Li \\ School of Humanities, Beijing University of Posts and Telecommunications, Beijing, China \\ Email: hopejk1@yahoo.com.cn \\ Zhihong Lu \\ School of Humanities, Beijing University of Posts and Telecommunications, Beijing, China \\ Email: zhihonglu2002@yahoo.com.cn
}

\begin{abstract}
Following rapid social development and educational policy orientation in China, higher institutions are developing new optional courses in English. One of these courses is interpreting for non-English majors (IFNEM), which requires a needs analysis (NA) at the beginning. However, few studies have been found on the NA of an IFNEM, empirical ones in particular. In the limited empirical research, merely sophomore students' needs were surveyed through a single questionnaire, leaving many practical issues to be further explored. To advance the current body of research, the authors of this paper designed a complex structured questionnaire based on Hutchinson and Waters's Framework for Analyzing Learning Needs, delivered it to 104 freshmen and 52 junior students and conducted follow-up interviews with eight of them who had given typical answers in this questionnaire. Such issues were investigated as students' motivation for taking an IFNEM, their anticipated goals and objectives of the course, course entry requirements (if there should be any), selection of teaching content and materials and teaching environments. Results showed that the students highly approved of establishing an IFNEM for mainly Surface Motivation and wished for no entry requirements; however, limited by their current English proficiency, they aimed to improve both interpreting skills and English listening and speaking abilities. This study attempts to offer insights into the curriculum design of IFNEM and other optional courses in English for higher institutions.
\end{abstract}

Index Terms - curriculum design, interpreting, needs analysis

\section{INTRODUCTION}

Following rapid social development and educational policy reorientation in China, a profound reform of College English teaching is now underway. Teaching guidelines have been modified, resulting in a shift in the teaching model from teacher-centeredness to student-centeredness, and a change in the teaching objective from grammatical competence to communicative competence. More obviously, higher institutions are now adjusting, altering and restructuring their English curricula. Colleges are developing new optional courses in English, which leaves the pressing question of how to design them.

The Ministry of Education of China (2007) stipulated in College English Curriculum Requirements that "the teaching of College English should follow the principle of providing different guidance for different groups of students and instructing them in accordance with their aptitude so as to meet the specific needs of individualized teaching" (p. 19). To design a course that meets students' specific needs, the first step is performing a Needs Analysis (NA). A NA plays a vital role in designing and carrying out any language course. It is "the best place" to start "when a curriculum is being developed from scratch for a completely new language program" (Iwai et al, 1999, p. 7), so it is especially useful for analysing the needs of a new optional course- Interpreting for Non-English Majors (IFNEM), which many universities have not yet established.

Little research can be found on interpreting in China, and the few studies on interpreting seem to be ill-proportioned. According to Liu \& Wang (2007), among the available 161 papers that study interpreting, only one third (31.1\%) focus on teaching practices (p. 38), and these studies tend to emphasize teaching methodology more than curriculum development (Wen, 2004, p. 66). A recent overview of the interpreting research in the past decade states that Non-English majors have never been the main subject of research, and empirical approaches have rarely been adopted. In fact, only three studies are of empirical nature in the current literature reviewed by Liu \& Wang (2007, pp. 38-39).

Even less research is available on the NA of IFNEM, empirical research in particular. There is only one empirical study conducted by Wang (2009) according to the authors' search through papers published in CSSCI Journals of English language teaching, which offered valuable suggestions on IFNEM through a NA of sophomore students of non-English majors after they had taken an interpreting course for one term (pp. 72-82). However, Wang's study 
surveyed only sophomore students of Non-English majors, leaving the NA of other grades in the dark. Besides, there are some practical issues to be further explored, which include students' motivation for taking an IFNEM, their anticipated goals and objectives of the course, course entry requirements (if there should be any), and selection of teaching content and materials. Besides, the survey instruments can be improved by using a better-founded questionnaire with more reference to NA theories and more instruments like follow-up interviews. All of these problems are what the authors of this paper intend to solve here.

To address those issues in the NA of IFNEM for other grades with improved instruments, the authors of this paper designed a questionnaire based on NA theories, delivered 156 questionnaires to both freshmen and junior non-English majors in the participating university and interviewed eight students after they had finished their questionnaires. The data analysis shed light on the following questions about the NA of the IFNEM:

1) Is it necessary to set up an IFNEM as an optional College English course?

2) Should there be any entry requirements for this course?

3) What motivation do the students have for taking an IFNEM?

4) What should be the goals and objectives of the IFNEM?

5) What teaching content and materials should be applied?

6) When and where should an IFNEM be held?

\section{LITERATURE REVIEW}

\section{A. Needs Analysis}

Needs Analysis (NA) became well established in the mid-1970s when learner-centered and communication-focused approaches to language teaching were gaining popularity. Deriving from English for Specific Purposes (ESP), NA is applicable to both ESP and English for general purposes. NA is a vital prerequisite for developing a course because "it forms a rational basis for all the other components of a systematic language curriculum" (Iwai et al, 1999, p. 7). Its importance in curriculum design has been widely recognized (Yalden, 2000; Brown, 2001; Hutchinson \& Waters, 2002; Shu, 2004; Wen, 2004; Ni and Liu, 2006).

A well accepted definition of NA was given by Brown (2001). He defined NA as "the activities involved in gathering information that will serve as the basis for developing a curriculum that will meet the learning needs of a particular group of students"(p. 35). In this definition, the "learning needs" mean "a gap or measurable discrepancy between a current state of affairs and a desired future state" (Berwick, 1989, p. 52). Simply put, they are "the gap between what is and what should be" (Brindley, 1989, p. 63).

\section{B. Target Situation Analysis and Present Situation Analysis}

Two situations should be investigated in an NA: the present situation ("what is") and the target situation ("what should be"). Accordingly, Target Situation Analysis (TSA) and Present Situation Analysis (PSA) are suggested.

TSA is "a needs analysis which focuses on students' needs at the end of a language course" (Robinson, 1991, p. 8).While TSA concerns the final results of satisfactory teaching, PSA aims to describe the learners' beginning situations. Since the IFNEM is new and lacks clearly phrased objectives (destination point), its NA should rely heavily on the PSA approach, making the most of the starting point. Moreover, PSA can provide TSA with necessary data on learners' strength and weakness in language, skills, learning experiences (Dudley-Evans and St. John, 1998, p. 125), paving the way for a well-informed decision on the destination point.

However, merely adopting the two approaches (PSA and TSA) would not be enough to find "the way" from "what is" to "what should be". Students" learning needs, the needs posed by social development and market demands should also be taken into account. An ideal curriculum design for interpreting (and translation) should have teaching that meets the learners' needs and market demands to the largest extent possible ( $\mathrm{Li} \& \mathrm{Hu}, 2006$, p. 61). The importance of integrating social considerations into the curriculum design has been echoed by other scholars as well (Shu, 2004; Hu, 2005; Zhang, 2007).

\section{Needs Analysis Model}

The first NA model for language teaching was proposed by Munby (1972), but it is too complex to "be applied in any comprehensive fashion to curriculum design" (Nunan, 2001, p. 149). Based on the Munbian Model, Hutchinson \& Waters (2002) created a more applicable framework for analyzing learning needs (pp. 62-63), which the authors of this paper adapted and employed as the theoretical basis for designing the questionnaire (available upon request). The correspondence between the questions in the questionnaire and the items in the framework is illustrated in Table 1. 
TABLE 1.

THE AUTHORS’ ADAPTED VERSION OF FRAMEWORKS FOR ANALYZING LEARNING NEEDS

\begin{tabular}{|c|c|}
\hline $\begin{array}{l}\text { The Authors'Adapted version of Hutchinson and Waters's } \\
\text { Framework for Analyzing Learning Needs }\end{array}$ & $\begin{array}{l}\text { Related Questions } \\
\text { in the Questionnaire }\end{array}$ \\
\hline \multicolumn{2}{|l|}{ Why are the learners taking the course? } \\
\hline - compulsory or optional; & Q17, Q3 \\
\hline - apparent need or not; & Q7, Q6, Q11 \\
\hline - Are job prospects involved? & Q5. \\
\hline - What do learners think they will achieve? & Q18, Q40 \\
\hline - What is their attitude towards the IFNEM course? Do they want to improve their English interpreting skills? & Q26, Q4, Q12, Q19 \\
\hline - What else also accounts for their taking this course? & Q27 \\
\hline \multicolumn{2}{|l|}{ How do the learners learn? } \\
\hline - What is their learning background? & Q7-11. Q13 \\
\hline - What is their concept of teaching and learning? & Q16, Q31 \\
\hline - What methodology will appeal to them? & Q32, Q38 \\
\hline - What sort of techniques are likely to bore/alienate them? & Q39 \\
\hline \multicolumn{2}{|l|}{ What resources are available? } \\
\hline - professional competence of teachers; & Q29-30 \\
\hline - teachers' knowledge of and attitude to interpreting training; & Q28 \\
\hline - materials; & Q35-37 \\
\hline - aids; & Q33 \\
\hline - opportunities for indirect learning of out-of-class activities & Q28 \\
\hline \multicolumn{2}{|l|}{ Who are the learners? } \\
\hline - age/sex/nationality; & Information available \\
\hline - What subject knowledge do they have? & Information available \\
\hline - What is their socio-cultural background? & Information available \\
\hline - What do they know already about Interpreting? & Q13-14 \\
\hline - What are their interests in teaching content? & Q35 \\
\hline - What teaching styles are they used to? & Q31-33 \\
\hline - What is their attitude to English and interpreting skills? & Q4, Q12, Q15 \\
\hline - Should they meet any entry requirements? If so, what requirements? & Q20, Q21 \\
\hline \multicolumn{2}{|l|}{ Where will the IFNEM course take place? } \\
\hline - Are the surroundings pleasant, dull, noisy, cold etc? & Q24, Q25, Q40 \\
\hline \multicolumn{2}{|l|}{ When will the IFNEM course take place? } \\
\hline - time of day; & Q23 \\
\hline - every day/once a week; & $\mathrm{Q} 40$ \\
\hline - full-time/part-time; & Q22 \\
\hline
\end{tabular}

\section{RESEARCH}

\section{A. Participants}

The participants consisted of 156 undergraduate students from six classes taught by the authors of this paper at their home university. Among them, there were 104 freshmen students (59 male, 56.7\%; 45 female, 43.3\%) majoring in E-commerce and Law, Telecommunication Engineering and Management and 52 junior students (28 male, $53.8 \%$; 24 female, $46.2 \%$ ) of three majors: Japanese, Electronic Engineering, Information and Communication Engineering. The junior students have taken the College English Test (Band-4) (CET-4). Their average total CET-4 scores ranged from 350 to 655 with an average of 533.18; their listening test scores in CET-4 ranged from 60 to 221 with an average of 151.73. Both groups took the questionnaires at the end of their respective school year.

Different from other freshmen, the freshmen participants in this sample attend International School, where all of their subjects are taught in English and their English skills progress faster than students from other schools of the university. In one year they cover what students of the other schools learn in two, so when they took the questionnaire at the end of their first year, they theoretically had the language proficiency of sophomores. Therefore their responses could reflect to some extent the needs of average sophomore students as well as intermediate and advanced learners among freshmen in other schools.

\section{B. Instruments}

Three instruments were used in this study. 


\section{Questionnaire}

The questionnaire (available upon request) was designed to analyze students' target needs (goals and objectives) and learning needs with special attention to their motivation, after surveying the necessity of establishing IFNEM. As mentioned before, the theoretical basis of the questionnaire was the authors' adapted version of Hutchinson and Waters's Learning Needs Framework (see Table 1).

In this questionnaire there were 41 questions in total, covering students' motivation, their present learning situation, their expectations on learning goals and objectives, teaching content, materials, and the teachers as well as other things. Among all the questions, 36 have open-ended constructions, allowing for a fill-in option after multiple choices. The questionnaire also contains tasks to put items in order of importance or preference.

The questionnaires were delivered and completed on line using a web-based English language training and research system, "Rofall." This system enables researchers to design complex structured questionnaires and obtain immediate results in excel format once the participants have finished all the questions. All the 156 questionnaires were collected and counted valid.

2. Data from a research report

In order to analyze social demands for an IFNEM, the authors of this paper utilized statistics from a macro investigation ("Report on constructing an undergraduate program for translation majors") done by School of Foreign Languages, Huazhong University of Science and Technology in 2009.

3. Focus group discussion and follow-up interview

The authors of this study held a focus group discussion with all of the 156 students in class immediately after they had submitted responses. The class discussion focused on the necessity of this new optional course. After scanning each student's responses of the questionnaire in the "Rofall" system, the authors interviewed eight students (four freshmen and four junior students) who had given typical or interesting answers. The interview lasted for 15 minutes each, exploring mainly their English backgrounds, general expectations on an IFNEM and reasons to give particular answers.

\section{RESULTS AND DISCUSSIONS}

\section{A. Need for an IFNEM}

Both Students' written and oral answers supported the establishment of an IFNEM as an English optional course. As shown in Table 2, 75\% said it was necessary to set up an IFNEM, and about $18 \%$ attached extremely high importance to this course. Only $7.69 \%$ didn't consider the course very necessary. Their reasons, according to the follow-up interview, are three-pronged: lack of interest, no future use and being incapable of interpreting with limited English abilities. On balance, these findings confirm the necessity to open IFNEM as an optional course of College English, meanwhile point out the need to tailor the course to non-English majors who have relatively low English proficiency.

TABLE 2.

NECESSITY OF ESTABLISHING AN IFNEM

\begin{tabular}{|l|l|}
\hline Question 17: What's your opinion on establishing an optional English course- Interpreting for non-English majors? \\
\hline Items & Percent \\
\hline Vitally necessary & 17.95 \\
\hline Necessary & 57.05 \\
\hline Not so necessary (Please give your reason ) & 7.69 \\
\hline Not necessary at all (Please give your reason) & 0.64 \\
\hline I don't know how necessary this course is & 15.38 \\
\hline Other (Please specify: & 1.28 \\
\hline
\end{tabular}

The need for IFNEM is more than obvious from the social context, when looking at the growing market demands for qualified interpreters and limited options for interpreting training. Statistics collected by the School of Foreign Languages, Huazhong University of Science and Technology in 2009 showed that among 40,000 professional translators and interpreters and 500,000 practitioners of related fields, as many as 90 percent were unqualified. There has been an urgent need for interpreters with both professional interpreting skills and strength in a certain field.

In fact, non-English major students have great potential to become such professional interpreters, because background knowledge, or subject knowledge, plays an integral part in the comprehension process of interpreting. The importance of background knowledge has been illustrated in Gile's Comprehension Equation of Interpreting (1995, pp. 80):

$$
\mathrm{C}=\mathrm{KL}+\mathrm{ELK}+\mathrm{A} \text {, }
$$

in which "C" stands for comprehension, "KL" is for "knowledge of the language", "A" means the active analysis of the interpreter, and "ELK" refers to "extra-linguistic knowledge" like subject knowledge. In fact, many members of the AIIC $^{1}$ are not English majors. Non-English majors with sound language proficiency often outperform English majors in interpreting practices, thanks to their abundant knowledge in certain fields. Therefore, non-English major students need to have access to interpreting training to tap their potential.

\footnotetext{
${ }^{1}$ AIIC: International Association of Conference Interpreters, the most authoritative organization of professional conference interpreters
} 
Presently there are only limited choices for interpreting training-within universities, such training mainly targets English majors, involving undergraduate programs for students who major in Translation and Interpretation and graduate programs for interpreting degrees in English departments. Off campus, interpreting training is offered by some companies, but those programs are yet to be standardized in both price and quality. This training needs to be expanded and revised to cover non-English major students. A possible solution is to offer courses like IFNEM.

In addition, IFNEM is also in line with the goals of College English set by the Ministry of Education of China: "to develop students' ability to use English in a well-rounded way, especially in listening and speaking" (Department of Higher Education, 2007, p. 18). Interpreting is communicative in nature, so the course can enhance students' listening and speaking abilities aside from interpreting skills, as believed by the overwhelming majority of participating students $(92.94 \%)$ (See Table 3)

TABLE 3.

BELIEFS ON THE IMRPROVEMENT OF LISTENING AND SPEAKING SKILLS FROM IFNEM

\begin{tabular}{|l|l|}
\hline \multicolumn{2}{|l|}{$\begin{array}{l}\text { Question 18. If such a course is offered, what influences do you believe the course would have on improving } \\
\text { your English listening and speaking abilities? }\end{array}$} \\
\hline Items & Percent \\
\hline It would be of great help. & 23.71 \\
\hline It would be very helpful. & 25.00 \\
\hline It would be helpful. & 44.23 \\
\hline It would be useless. & 1.28 \\
\hline It would have a negative impact. & 0 \\
\hline I am not sure whether it would be helpful. & 5.78 \\
\hline Other (Please specify: & 0 \\
\hline
\end{tabular}

\section{B. Entry Requirements of IFNEM}

Interpreting is "a practice requiring comprehensive capabilities including observing, listening, speaking, writing and reading” (Mei, 2000, p. 8), especially mastery of listening and speaking abilities. For English majors, interpreting courses are not opened until the third or fourth year of undergraduate programs, when they become "ready" with better English proficiency. Non-English majors, on the other hand, seem to be less prepared due to insufficient training of English listening and speaking skills. Therefore the authors suggested the use of entry requirements and asked students for their opinions.

Only about two thirds (63.46\%) approved of a threshold score for IFNEM (Table 4). The rest (36.54 \%) disagreed, among which freshmen opposed more strongly, giving comments like "WE WERE BORNED EQUALLY! (sic)"-fairness of education was one major concern that both grades shared $(77.14 \%)$ according to their written comments. Another reason was that they hoped their interest in interpreting to be considered (45.71\%). Three freshmen in the follow-up interviews expressed the worry that their low scores in entry exams of IFNEM might deny their chance to take this course, yet they had genuine interest in learning interpreting. One junior student said what an IFNEM should teach was merely learning method, which wouldn't require high language proficiency, so there should be no entry requirements.

TABLE 4.

WHETHER TO HAVE ENTRY REQUIREMENTS FOR IFNEM

\begin{tabular}{|l|l|l|}
\hline \multicolumn{2}{|l|}{ Question 20: Do you think there should be threshold scores for admission to Interpreting for non-English majors? } \\
\hline Items & Agree & Disagree(Please specify: \\
\hline Percent (total) & 63.46 & 36.54 \\
\hline Percent(freshmen) & 62.50 & 37.50 \\
\hline Percent(Juniors) & 65.39 & 34.61 \\
\hline
\end{tabular}

Despite the ideal of equal accessibility to this course, $53.85 \%$ didn't think they were ready to take an IFNEM with their present English listening and speaking abilities, and $12.18 \%$ gave negative answers to this question, as seen in Table 5. Interestingly, freshmen were more confident - there were fewer freshmen (10.58\%) who gave a resolute "No" answer compared to juniors (15.38\%). However, this might be related to freshmen's less certainty about their own English proficiency (11.54\%), compared with older students (7.69\%). 
TABLE 5

READINESS TO TAKE IFNEM WITHOUT ENTRY REQUIREMENTS

\begin{tabular}{|l|l|l|l|}
\hline \multicolumn{3}{|l|}{ Question 13: Do you think you are fully prepared to learn interpreting skills with your present English listening and speaking abilities? } \\
\hline Items & Percent (total) & Percent (juniors) & Percent (freshmen) \\
\hline I think so. & 19.87 & 19.23 & 20.19 \\
\hline $\begin{array}{l}\text { Not right now, But I would like to try after I improve } \\
\text { my English listening and speaking abilities. }\end{array}$ & 53.85 & 55.77 & 52.88 \\
\hline No. & 12.18 & 15.38 & 10.58 \\
\hline I don't know, but want to give it a try. & 3.85 & 1.92 & 4.81 \\
\hline I don't know and I don't want to try. & 10.27 & 7.69 & 11.54 \\
\hline Other (Please specify: & 0 & 0 & 0 \\
\hline
\end{tabular}

Having IFNEM accessible to every student might be an ultimate aim, but in reality it would be too difficult to ensure satisfactory education for students with diverse needs, since a large class size and students' various English backgrounds would pose a great challenge to teaching efficiency and effects, as proved by Wang's empirical study (2009, p. 78). With the limited teaching resources in China at present, a more realistic and convenient solution seems to be adopting entry exams or a placement test, so as to facilitate teaching and ensure learning achievements.

Students who approved of entry requirements were polled on types of entry exams. As seen in Table 6, most of them preferred either an oral English test before class $(40.38 \%)$ or a listening test of CET-4 (21.15\%); around one third $(30.76 \%)$ advised CET-4 total scores and an interpreting test before class. Moreover, $11.54 \%$ of respondents suggested other factors to be referred to, like learners' learning motivation and class performance in other courses. As for the threshold marks of entry exams, students were asked to put down a number from 1 to 100 . Their answers ranged from 60 to 80 , with an average of 71.33 for the speaking test before class and 73.75 for the listening test of CET- 4 .

TABLE 6

PREFERRED ENTRY EXAMS FOR IFNEM

\begin{tabular}{|l|l|}
\hline Question 21: If there should be threshold scores for this course, which exam scores should be taken into consideration? (Multi-answer) \\
\hline Items & Percent \\
\hline Oral English test before class & 40.38 \\
\hline Listening test of CET-4 & 21.15 \\
\hline CET-4 & 15.38 \\
\hline Interpreting test before class & 15.38 \\
\hline Other (Please specify: & 11.54 \\
\hline
\end{tabular}

There is no consensus among teachers on which entry exam to select for an IFNEM. Chi (2007) recommended CET-4 on the grounds that passers of CET-4 were supposedly with adequate English vocabulary, listening and speaking abilities (p. 126). However, Guo's empirical study on IFNEM for graduate students (2009) proved CET-6 to be a proper measurement. The authors of this paper would suggest CET-4 plus a listening \& speaking test before class. In fact, no matter what exam to take, it should be valid and reliable, capable of assessing students' comprehensive ability to use English, especially listening and speaking skills. As for the exact score of the entry requirements, more research, empirical study in particular, is called for in the future.

\section{Motivation}

Analyzing motivation is critical in a NA of a language curriculum because motivation strongly influences learners' learning needs (Ni and Liu, 2006, p. 22). According to Biggs (1987), motivation can be categorized into Surface Motivation (Instrumental Motivation) and Deep Motivation. Surface Motivation "is to meet requirements minimally; a balancing act between failing and working more than is necessary". Deep Motivation is "intrinsic interest in what is being learned; to develop competence in particular academic subjects" (p. 3). In other words, Surface Motivation is extrinsic by nature and related to one's future, while Deep Motivation is intrinsic and usually without direct link to one's future or economic interests, like one's interest in the language and culture (Wen, 2001, p. 105).

Students' motivation for learning English and interpreting were both surveyed. Data in Table 7 indicate that the students' motivation for learning English was mainly instrumental (74.37\% in total, items C, D and F) while their Deep Motivation accounted for only $10.9 \%$ (Item A). The students' dominant motivation for learning English was to enhance comprehensive ability (36.54\%) and to become more competitive in the job market (34.62\%). These findings were consistent with their motivation for taking an IFNEM course-to increase their comprehensive ability, especially listening, speaking and communicative abilities (Table 8, 69.23\%, Item B and E), and to prepare for future use of interpreting skills, as $76.92 \%$ of them (Table 9) contained interpreting in their possible occupations after graduation. 
TABLE 7

MAIN PURPOSES TO LEARN COLLEGE ENGLISH

\begin{tabular}{|l|l|}
\hline Question 3: Your main reason/purpose to learn English in college is: \\
\hline Items & Percent \\
\hline A. I love English and am very interested in learning English & 10.90 \\
\hline B. I need to communicate with others in English in daily life & 11.54 \\
\hline C. To improve my comprehensive ability & 36.54 \\
\hline D. To become more competitive in the future (job-hunting, going abroad, etc.) & 34.62 \\
\hline E. No special purpose, have to learn English in college & 3.21 \\
\hline F. To get the credits of English courses and be able to graduate & 3.21 \\
\hline G. To meet the expectations of my family & 0 \\
\hline H. To win the acclaim of the teacher and fellow students & 0 \\
\hline I. Other (Please specify: & 0 \\
\hline
\end{tabular}

TABLE 8

STUDENTS' MOTIVATION FOR TAKING AN IFNEM

\begin{tabular}{|l|l|}
\hline Question 19: If you select this course, you would do so mainly for: & Percent \\
\hline Items & 17.31 \\
\hline A. Learning interpreting skills and self-training methods of interpreting. & 47.44 \\
\hline B. Improving English listening and speaking abilities through interpreting exercises. & 4.49 \\
\hline C. Preparing for interpreting tests, to be more competitive in job-hunting with a certificate of interpreting. & 8.33 \\
\hline D. Enhancing cross-cultural communicative ability. & 21.79 \\
\hline E. Promoting English communicative ability. & 0.64 \\
\hline F. Other (Please specify: & .
\end{tabular}

TABLE 9

CAREer PlanNing NEEDS

\begin{tabular}{|l|l|}
\hline \multicolumn{2}{|l|}{ Question 5: Is interpreting one of your possible occupations after graduation? } \\
\hline Items & Percent \\
\hline Definitely & 21.79 \\
\hline Probably & 55.13 \\
\hline Probably not & 14.10 \\
\hline Definitely not & 4.49 \\
\hline Don't know & 4.49 \\
\hline Other (Please specify: & 0 \\
\hline
\end{tabular}

It comes as no surprise that these Non-English major students had a pragmatic attitude towards IFNEM. Research on motivation of Chinese non-English major students has proved that they learn English courses mainly for Surface Motivation (Qin, 2002; Tang, 2005); while English major students have more Deep Motivation (Gao et al, 2003a, p. 36), which grows over school years (Wen, 2001, p. 106).

Since non-English major students' motivation is more extrinsic than intrinsic, the teaching goals, objectives, content, and materials of IFNEM should be adjusted accordingly, different from those of interpreting course for English majors. In addition, IFNEM should also attempt to increase students' Deep Motivation, which plays a more significant role in learning than Surface Motivation, with its greater influence over learners' learning beliefs, strategies (Wen, 2001, 9. 109) and involvement (Gao et al, 2003b, p. 36).

\section{Goals and Objectives}

Motivated by extrinsic factors, the students prioritized improvement of English listening, speaking abilities (47.44\%) and communicative ability $(21.79 \%)$ in the goals and objectives of an IFNEM, and considered interpreting skills of secondary importance-only $17.31 \%$ listed it as the primary goal (See Table 8 above). This is because, according to respondents' written and oral responses, some of them were not fully prepared to practice interpreting due to their limited listening and speaking abilities. Nevertheless, many stated that they would like to learn interpreting skills for future use and believed IFNEM should be useful to enhance other English skills. It seemed that interpreting in their opinions were icing on the cake while listening and speaking abilities more fundamental.

Students' emphasis on listening and speaking abilities can be explained by analyzing data from Table 10 and Table 11 . Among English skills, students regarded speaking and listening skills to be the most important, with percentages of 46.79 and 39.74 respectively (Table 10). However, these two crucial skills were also their weakest. The combined percentages of students who chose listening and speaking as their first, second and third weakest skills were 48.08 and 55.77 respectively (See Table 11). That may account for their preferences on improving the two skills first. 
TABLE 10

MOST IMPORTANT ENGLISH SKILLS

\begin{tabular}{|l|l|l|l|l|l|l|}
\hline \multirow{2}{*}{ Question 6: How important are the following skills to you? Please put them in order of Importance. } \\
\hline \multirow{2}{*}{ Items } & Order of Importance & \multicolumn{4}{l|}{} \\
\cline { 2 - 8 } & 1 & 2 & 3 & 4 & 5 & 6 \\
\hline Listening & 39.74 & 46.79 & 8.33 & 3.21 & 1.92 & 0.00 \\
\hline Speaking & 46.79 & 36.54 & 10.26 & 5.13 & 0.64 & 0.64 \\
\hline Reading & 8.33 & 8.33 & 39.10 & 24.36 & 13.46 & 7.05 \\
\hline Writing & 1.92 & 3.21 & 11.54 & 42.95 & 21.15 & 18.59 \\
\hline Translation (in written form) & 0.00 & 2.56 & 4.49 & 8.97 & 35.26 & 48.72 \\
\hline Interpreting (oral translation) & 3.21 & 2.56 & 26.28 & 15.38 & 27.56 & 25.00 \\
\hline
\end{tabular}

TABLE 11

WEAKEST ENGLISH SKILLS

\begin{tabular}{|l|l|l|l|l|l|l|}
\hline Question 7: Which skills are you weak at? Please put them in order (the first one being your weakest): \\
\hline \multirow{2}{*}{ Items } & Order of Weakness & \multicolumn{5}{l|}{} \\
\cline { 2 - 8 } & 1 & 2 & 3 & 4 & 5 & 6 \\
\hline Listening & 10.26 & 17.95 & 19.87 & 12.18 & 21.79 & 18.59 \\
\hline Speaking & 19.23 & 20.51 & 16.03 & 18.59 & 15.38 & 9.62 \\
\hline Reading & 2.56 & 5.13 & 5.77 & 15.38 & 18.59 & 50.64 \\
\hline Writing & 10.90 & 11.54 & 17.31 & 21.79 & 23.72 & 14.74 \\
\hline Translation (in written form) & 3.21 & 25.64 & 23.08 & 27.56 & 17.95 & 3.21 \\
\hline Interpreting (oral translation) & 53.85 & 19.23 & 17.95 & 4.49 & 2.56 & 3.21 \\
\hline
\end{tabular}

However, this does not necessarily mean that they had little intention to learn interpreting. In Table 11, the majority of them $(91.03 \%)$ saw interpreting their first, second and third weakest skill. Most participating students expressed their desire to learn fundamental knowledge and general skills of interpreting in the written responses to an open-ended question on learning goals. Undoubtedly an IFNEM should focus on interpreting training, preparing students for practical needs of interpreting in the future.

To summarize, to meet the needs of non-English majors, the goals and objectives of an IFNEM should be double-fold: to improve both students' interpreting skills as well as English listening and speaking abilities in accordance with their present language proficiency. These goals also agree to some extent with the objectives of the College English curricula for non-English majors, i.e., to improve students' comprehensive ability, especially listening, speaking and communicative ability (Department of Higher Education, 2007, p. 18).

\section{E. Teaching Content and Materials}

With these goals and objectives, students anticipated to learn teaching content that integrated training of both interpreting and other English skills. As for what aspects to learn in interpreting, students preferred those they deemed more useful and interesting. Seen from Table 12, they had preference for interpreting skills and practices (with a combined percentage of 89.66) and application of translation software (72.41\%), while exhibiting less interest in a brief introduction to interpreting $(65.51 \%)$, which was believed to be less important $(5.17 \%)$ as demonstrated in Table 13 .

TABLE 12

NEEDS ANALYSIS ON TEACHING CONTENTS

\begin{tabular}{|l|l|l|}
\hline \multicolumn{2}{|l|}{ Question 35: What would you like to learn in this course? (You can choose more than one answer) } \\
\hline Items & Number & Percent \\
\hline Interpreting skills & 52 & 89.66 \\
\hline Interpreting practices & 52 & 89.66 \\
\hline Application of translation software & 42 & 72.41 \\
\hline Brief introduction to interpreting & 38 & 65.51 \\
\hline Others & 0 & 0 \\
\hline
\end{tabular}

TABLE 13

MOST IMPORTANT ELEMENTS OF TEACHING CONTENTS

\begin{tabular}{|l|l|l|}
\hline $\begin{array}{l}\text { Question 35: What would you like to learn in this course? (multi-answers) } \\
\text { (please put down your answer in the order of importance, the first choice being the most important) }\end{array}$ \\
\hline Items & Number & Percent \\
\hline "Interpreting skills" as the first choice & 27 & 46.55 \\
\hline "Interpreting practices" as the first choice & 26 & 44.83 \\
\hline "Brief introduction to interpreting" as the first choice & 3 & 5.17 \\
\hline "Application of translation software" as the first choice & 1 & 1.72 \\
\hline
\end{tabular}

Specifically, in terms of teaching materials for interpreting practices (Table 14), students favored easier materials which were appropriate for their English abilities and more likely to be used in the future, including those for general purposes $(24.36 \%)$ and daily conversations $(23.72 \%)$. They accepted to learn selected materials in classic textbooks $(20.51 \%)$ but showed little interest in interpreting famous people's speeches and talk shows (both 12.82\%), which 
appeared more difficult and less relevant to their future work.

TABLE 14

MATERIALS PREFERRED IN INTERPRETING PRACTICES

\begin{tabular}{|l|l|}
\hline Question 37: What materials do you prefer to use in interpreting practices? & Percent \\
\hline Items & 24.36 \\
\hline Materials containing general interpreting circumstances, like tourism, foreign affairs, accompany interpretation. & 23.72 \\
\hline Daily conversation & 20.51 \\
\hline Selected materials in classic textbooks & 12.82 \\
\hline Famous people's speeches & 12.82 \\
\hline Talk show of celebrities & 3.21 \\
\hline Other (Please specify: & 1.28 \\
\hline Materials for simultaneous interpretation & 1.28 \\
\hline More difficult Materials, i.e. Premier Wen's press conference & \\
\hline
\end{tabular}

Besides interpreting knowledge and skills, around $70 \%$ agreed to have class activities in order to improve their basic English abilities (Table 15). It can be seen from Table 16 that they hoped to improve pronunciation (42.5\%), listening (35\%) and speaking skills (22.5\%). This is related to their English education history: unlike English majors, they usually have no separate course on English pronunciation and intonation and fewer chances to practice English listening and speaking skills, which leads to their less confidence in these abilities.

TABLE 15

NEEDS ANALYSIS ON OTHER ENGLISH SKILLS

\begin{tabular}{|l|l|}
\hline \multicolumn{2}{|l|}{$\begin{array}{l}\text { Question 36: Do you agree that the teacher should include in class training activities aiming to } \\
\text { improve students' basic English skills (such as, pronunciation, listening, speaking, etc)? }\end{array}$} \\
\hline Items & Percent \\
\hline Agree & 68.97 \\
\hline Disagree & 31.03 \\
\hline
\end{tabular}

TABLE 16

ENGLISH SKILLS THAT NEED IMPROVING

\begin{tabular}{|l|l|l|}
\hline \multicolumn{4}{|l|}{$\begin{array}{l}\text { Question 36.1: If you need the teacher to carry out activities in class to help you improve English } \\
\text { pronunciation, listening and speaking abilities, which abilities do you need in particular (multi-answers)? }\end{array}$} \\
\hline Items & Number & Percent \\
\hline Pronunciation & 17 & 42.50 \\
\hline English listening ability & 14 & 35.00 \\
\hline English speaking ability & 9 & 22.50 \\
\hline
\end{tabular}

However, about one third (31.03\%) disapproved of class activities designed for this purpose (Table 16). A major reason given by one junior interviewee was that those activities were unnecessary for advanced learners, who aspired to learn something beyond fundamentals. Another reason was that those skills could be honed by students independently after class, utilizing readily available Internet resources and computer software; the class time was too precious to be wasted on those activities.

\section{F. Scheduling and the Teaching Environment}

For universities planning to establish IFNEM, a practical issue is when to start it and what teaching environment it requires. Based on his teaching experiments, Wang (2009) advised to start IFNEM in the second term of the sophomore year after students had finished a preparatory course "Translation for non-English majors" (pp. 80-81). Different from his suggestion, the students surveyed hoped to have an IFNEM in the first term of the second year (juniors, $42.31 \%$ ) or the first term of the first year (freshmen, 28.85\%) (See Table 17).

TABLE 17

SCHEDULING OF OFFERING THE IFNEM

\begin{tabular}{|l|l|l|l|}
\hline Question 22: When is it most appropriate to offer this course? & Percent (freshmen) \\
\hline Items & Percent (total) & Percent (juniors) & 28.85 \\
\hline The 1st term of the 1st year & 15.38 & 8.65 & 7.69 \\
\hline The 2nd term of the 1st year & 9.62 & 10.58 & 7.69 \\
\hline The 1st term of the 2nd year & 30.77 & 42.31 & 9.62 \\
\hline The 2nd term of the 2nd year & 16.03 & 19.23 & 21.15 \\
\hline The 1st term of the 3rd year & 15.38 & 12.5 & 13.46 \\
\hline The 2nd term of the 3rd year & 5.13 & 0.96 & 11.54 \\
\hline The 1st term of the 4th year & 4.49 & 0.96 & 0 \\
\hline The 2nd term of the 4th year & 0 & 0 & 0 \\
\hline Other (Please specify: & 3.21 & 4.81 & \\
\hline
\end{tabular}


The freshmen's wish to open this course in the first year is related to their better English proficiency, higher motivation and ambition as well as time constraints in other school years. As mentioned before, the freshmen surveyed were from International School, where they had more chances and higher motivation to learn English. In one year they covered what students of other schools learned in two, so they were more confident about their English proficiency. Besides, according to the class discussion, most of International School students aspired to go abroad after graduation, so they had higher motivation for learning English and hoped to take more English courses as early as possible. Another outstanding reason lied in their busy scheduling in other school years. The follow-up interviews revealed that students of Science or Engineering majors were usually busiest with their own subjects in the sophomore year, preventing them from taking optional courses. However, being highly-motivated and confident language learners, they would love to take the opportunity to learn interpreting. So they expressed the wish of having IFNEM at the beginning of freshmen year when they had more free time.

Taking students' opinions into account, the authors of this paper believe that IFNEM should be started with a careful consideration of the overall curricula and students' specific English backgrounds. When to open IFNEM depends on the students' English proficiency levels other than their grades. With college students' increasing English abilities thanks to their previous English education, it is of feasibility to open IFNEM in the freshman year. For this idea, more empirical studies need to be carried out.

In terms of the appropriate time to conduct IFNEM, the two groups put priority on the first evening class (18:30 - 20:30 p.m., 48.72\%), the first morning class (08:00-10:00 a.m., 19.23\%) and the second morning class (10:00-12:00 a.m., 16.03\%) (See Table 18). Three junior students and two freshmen students reported that they chose morning and evening because they were usually free in the evening and more energetic in the morning.

TABLE 18

SCHEDULING OF CONDUCTING THE IFNEM

\begin{tabular}{|l|l|l|l|}
\hline \multicolumn{4}{|l|}{ Question 23: When is it most appropriate to conduct this course? } \\
\hline Items & Percent (total) & Percent (juniors) & Percent (freshmen) \\
\hline 18:30-20:30 p.m. & 48.72 & 23.08 & 61.54 \\
\hline $08: 00-10: 00$ a.m. & 19.23 & 44.23 & 6.73 \\
\hline 10:00-12:00 a.m. & 16.03 & 21.15 & 13.46 \\
\hline $15: 30-17: 30$ p.m. & 8.97 & 9.62 & 8.65 \\
\hline 13:30-15:30 p.m. & 4.49 & 1.92 & 5.77 \\
\hline Other (Please specify: & 2.56 & 0 & 3.85 \\
\hline
\end{tabular}

In agreement with Wang's findings (2009), the paramount class size according to the students is around 20 as indicated in Table 19. Larger class sizes were also acceptable, like classes of about 30 (10.9\%) and 40 (11.54\%).

TABLE 19

NUMBER OF STUDENTS IN AN IFNEM CLASS

\begin{tabular}{|l|l|l|l|}
\hline Question 24: The number of students enrolled in this course should be fewer than_. \\
\hline Items & Percent (total) & Percent (juniors) & Percent (freshmen) \\
\hline 24 & 31.41 & 50 & 22.12 \\
\hline 16 & 28.21 & 32.7 & 25.96 \\
\hline 8 & 14.1 & 5.77 & 18.27 \\
\hline 40 & 11.54 & 5.77 & 14.42 \\
\hline 32 & 10.9 & 5.77 & 13.46 \\
\hline Other (Please specify: & 3.85 & 0 & 5.77 \\
\hline
\end{tabular}

There are some basic requirements on the teaching environments as Table 20 suggests. A language lab (61.54\%), multi-media facilities $(60.98 \%)$, and computers with access to the internet $(43.59 \%)$ were advised. What's worth noticing is students' emphasis on movable tables and chairs, which many language labs do not have, yet they are very useful in facilitates communication and the simulations of real situations of interpreting.

TABLE 20

THE TEACHING ENVIRONMENT AND FACILITIES OF IFNEM

\begin{tabular}{|l|l|l|l|}
\hline Question 25: The teaching environment and facilities should include: (You can choose more than one answer) \\
\hline Items & Percent (total) & Percent (juniors) & Percent (freshmen) \\
\hline Language lab & 61.54 & 67.31 & 58.65 \\
\hline Multi-media facilities & 60.9 & 67.31 & 57.69 \\
\hline Movable tables and chairs & 47.44 & 44.23 & 49.04 \\
\hline Computers with access to the Internet & 43.59 & 48.08 & 41.35 \\
\hline Other (Please specify: & 3.85 & 0 & 5.77 \\
\hline
\end{tabular}

\section{CONCLUSION}

From the analysis above, we can conclude that it is highly necessary to set up an IFNEM as an optional College English course due to social demands and students' needs. Despite the students' ideal to have equal access to an IFNEM 
without entry requirements, a more realistic solution might be having entry exams or a placement test, utilizing well validated and reliable instruments to assess their English proficiency, especially listening and speaking abilities. Further experiments will be needed to determine which tests to take and what the threshold marks should be.

Since students would take IFNEM mainly for instrumental motivation and some of them are not fully prepared to practice interpreting with the current English backgrounds, the teaching goals and objectives of IFNEM should be improvement of both interpreting skills and other language abilities, English listening and speaking abilities in particular. In interpreting practices, the authors recommend materials related to the students' own majors so as to tap their potentials to become interpreters with strength in a certain field. As for exercises of English listening and speaking, they should be included in class, but to a limited degree and mainly be done by students independently after class.

Students hoped to take an IFNEM in their freshmen and sophomore year, on the grounds of their better language proficiency, higher motivation and time constraints in other school years. They agreed to have IFNEM either in the evening or in the morning, when they were usually free and more concentrated. They also expected an IFNEM class of small size, with around 20 students being the ideal and 40 at its worst. The teaching environments were expected to have facilities including multi-media appliances, computers and movable tables and chairs, which can facilitate communication and simulation of real interpreting situations.

This study is based mainly on students' needs. However, due to practical reasons, it lacks analysis on the needs from other sources, such as teachers, experts, administrators, employers, institutions, and nations, whose needs "may also have a bearing on the language teaching and learning situation" (Brown, 2001, p. 20). The data on the needs of the society in this paper is secondhand and requires updating, which calls for a more authoritative and comprehensive survey done by joint efforts.

The NA of IFNEM is a continual process. This paper focuses on students' initial needs, while their ongoing needs are yet to be discovered during the practice of teaching. Moreover, in the future NA of an IFNEM, more approaches are advised, like Pedagogic Needs Analysis and Deficiency Analysis (Dudley-Evans and St. John, 1998, p. 125).

\section{ACKNOWLEDGMENT}

This paper is the product of the Humanities \& Social Science Research Project Empirical Study on Sino-American Co-teaching Mode of College English Audio-video Speaking Class (EAVSC) (2011RC1110) supported by "the Fundamental Research Funds for the Central Universities".

This study is made possible by the Beijing city-level research project Research on Intelligent Language Skill Training supported by Beijing municipal Commission of Education.

While writing and revising the paper, the authors received great help from the Dartmouth-BUPT "Video Interaction-Based Education (VIBE) Language Exchange" Program.

\section{REFERENCES}

[1] Berwick, R. (1989). Needs assessment in language programming: from theory to practice. In: Johnson, R. K. (ed.), The second language curriculum. Cambridge: Cambridge University Press, 52.

[2] Biggs. J. B. (1987). Student approaches to learning and studying: Study process questionnaire manual. Burwoo, Victoria: Australian Council for Educational Research Limited.

[3] Brindley, G. P. (1989). The role of needs analysis in adult ESL program design. In: Johnson. R. K.(Ed.), The second language curriculum. Cambridge: Cambridge University Press, 63-72.

[4] Brown, D. (2001). The elements of language curriculum: A systematic approach to program development. Oxford: Pergamon Press.

[5] Chi, Huanling. (2007). Research on introduction to interpretation for non-English major. Journal of Anhui University of Technology (Social Sciences) 24. 6, 126-127.

[6] Department of Higher Education. (2007). College English curriculum requirements. Beijing: Foreign Language Teaching and Research Press.

[7] Dudley-Evans, T., and St. John, M. (1998). Developments in ESP: A multi-disciplinary approach. Cambridge: Cambridge University Press.

[8] Gile, Daniel. (1995). Basic concepts and models for interpreter and translator training. Amsterdam/Philadelphia: John Benjamins Publishing Company.

[9] Gao, Y.H., Zhao, Y., Cheng, Y., and Zhou, Y. (2003). Motivation types of Chinese College Undergraduates. Modern Foreign Languages 26.1, 28-38.

[10] Gao, Y.H., Zhao, Y., Cheng, Y., and Zhou, Y. (2003). The relationship between types of English learning motivation and motivational intensity-A quantitative investigation on Chinese College undergraduates. Foreign Language Research 1, 60-64.

[11] Guo, Jing. (2009). An empirical study of interpreting training with a certain filed for non-English major postgraduate students. Journal of Southeast University (Philosophy and Social Science) 11.Supplement, 258-261.

[12] Hu, Zhinv. (2005). The principles of College English course design system and its practice. Journal of Anhui University of Technology (Social Sciences) 22.2, 71-73.

[13] Hutchinson, T. and Waters, A. (2002). English for specific purpose. Shanghai: Shanghai Foreign Language Education Press.

[14] Iwai, T., Kondo, K., Limm, S. J. D., Ray, E. G., Shimizu, H., and Brown, J. D. (1999). Japanese language needs analysis. http://www.nflrc.hawaii.edu/Networks/NW13/NW13.pdf (accessed 19/10/2010). 
[15] Li, Defeng, \& Hu, Mu. (2006). Curriculum development in translation education: A learner-centered approach. Journal of Foreign Languages 2, 59-65.

[16] Liu, Shaolong, \& Wang, Liuqi. (2007). Review and analysis of the research on interpreting in China in the past decade. Journal of Guangdong University of Foreign Studies 18.1, 37-40.

[17] Mei, Deming. (2000). An Advanced Course of Interpretation. Shanghai: Shanghai Foreign Language Education Press.

[18] Munby, J. (1978). Communicative syllabus design. Cambridge: Cambridge University Press.

[19] Ni, Chuanbin, \& Liu, Zhi. (2006).Properties of Needs for a Foreign Language. Foreign Languages and Their Teaching 2 , 21-24.

[20] Nunan, David. (2001). Second language teaching and learning. Beijing: Foreign Language Teaching and Research Press. Heinle \& Heinle /Thompson Learning Asia.

[21] Qin, Xiaoqing. (2002). Motivation perspectives, motivation theories in psychology and implications for L2 motivation researchers. Foreign Language Research 4, 74-79

[22] Robinson, P. (1991). ESP today: A practitioner's guide. UK: Prentice Hall International (UK) Ltd.

[23] School of Foreign Languages, Huazhong University of Science \& Technology. (2009). Research report IV: Report on constructing an undergraduate program for translation majors. http://focus.hustonline.net/html/2009-6-19/63763.shtml (accessed 9/6/2010).

[24] Shu, Dingfang. (2004). FLT in China: Problems and suggested solutions. Shanghai: Shanghai Foreign Language Education Press.

[25] Tang, Wenli.(2005).Investigation and analysis on the influence motivation have on oral English learning. A study of the influence of motivation elements on oral English learning. Foreign Language Education 26.2, 65-68

[26] Wang, Jinbo. (2009). A needs survey of non-English major undergraduates in translation teaching. Foreign Language World 5, $72-82$.

[27] Wen, Jun. (2004). On the study of translation curriculum. Journal of Foreign Languages 3, 64-70.

[28] Wen, Qiufang. (2001). Developmental patterns in motivation, beliefs and strategies of English learners in China. Foreign Language Teaching and Research 33.2, 105-109

[29] Yalden, J. (2000). Principles of Curriculum design for Language Teaching. Beijing: Cambridge University Press.

[30] Zhang, Jingrong. (2007). A foreign language learning demand analysis and investigation of non-English major students. Journal of Guiyang University (Social Sciences) 3, 92-95.

Ping Li was born in Weifang, Shandong Province in 1982. She received her M. A. degree of Foreign Linguistics and Applied Linguistics at Nankai University, Tianjin, China in 2007.

She is currently a Lecturer in School of Humanities, Beijing University of Posts and Telecommunications, Beijing, China. Her research interests include computer-assisted language learning, English language teaching and translation \& interpretation.

Zhihong Lu was born in Urumchi, Xinjiang Uyghur Autonomous Region in 1963. She received her B. A. degree of English Education from Capital Normal University, Beijing, China in 1985. She attended the Graduate Training Program at Beijing Foreign Studies University during 1993-1994, specializing in applied linguistics.

She is currently a Professor and Supervisor of master students in School of Humanities, Beijing University of Posts and Telecommunications, Beijing, China. Her research interests include applied linguistics, especially, computer-assisted language learning, language teaching, and sociolinguistics. 